NRP 130119026 - KP B PEREKONOMIAN INDONESIA

\title{
Explanation About the Reasons of Why Digital Platform Being a Solution for MSME Resilience
}

The development of the era increasingly encourages digitalization in various fields including the economic sector, this is evidenced by the number of digital platforms that are increasingly available and of course making it easier for business owners to transact with users or customers. One of them that affected is MSME owners which also face the current instability of the economy, MSMES or Micro, Small and Medium Enterprises are a form of productive economic business owned by individuals or business entities in accordance with various provisions that have been set and based on the Act. Law or Undang-Undang No. 20 of 2008 which has a strategic role and affects the growth of gross domestic product. However, due to the situation and condition of the Covid-19 pandemic as one of the virus outbreaks that has occurred since the beginning of 2020 and continues it has caused various impacts in many areas of life that tend to decline, such as in terms of the economy caused by policies in reducing and breaking the chain of virus spread like social distancing that makes people reluctant to congregate and decline in people's purchasing power. There are survey results from the Central Statistics Agency of the Republic of Indonesia which explains that in September 2020 there was a decrease in income of micro and small businesses by $84 \%$ and medium and large businesses by $82 \%$ as well as a survey from ADB which stated that $6,1 \%$ of MSMEs in Indonesia had reduced their income and workers in large number of scale. This depression was affected in sector of accommodation, food and beverage, transportation, manufacturing \& construction and also trade sector (Tayibnapis et al., 2021).

Digital Platforms is certainly one of the solutions and the best way to have the opportunity to get excess profits, especially in the unstable global economic situation and conditions due to the impact of the Covid-19 pandemic. Digital platforms are a space of several software and many applications that are evidence of the development of industry 4.0 like the e-commerce which is become digital platforms in business and economy sector with many main goal such as the facilitates marketing activities optimally and increase the potential to improve the performance of MSME owners (Andriani et al., 2019). In the current digital era, MSME owners should be more open to the development of information technology which will 
certainly help owners to compete and develop business in this digital era with uncertain global economic conditions is also evidenced by survey data from the Association of Indonesian Internet Network Providers which states that there is an increase in the percentage of internet users in Indonesia which is also caused by easy access for the public to get smartphones, so that this can be evidence that supports that there is an opportunity for MSMEs to be able to join the digital platform in order to take more advantage of conveniences that are obtained afterwards (Febriyantoro \& Arisandi, 2018).

In addition to being a solution in supporting the resilience of MSMEs, digitalization is also a form of recovery, so that the owners can survive in the midst of Covid-19 pandemic which cannot be separated from the various benefits of using information technology (Tayibnapis et al., 2021). Efforts to immediately apply digitalization to MSMEs will also help owners to determine competitiveness in competitive digital era, although that currently it is still relatively small and tends to have little interest and innovation form MSME owners who have implemented digitalization and played a role in available digital platforms (Tayibnapis et al., 2021). Through of various explanations, the reasons of why digital platforms being a solution for MSME resilience is because digitalization offers many benefits and conveniences for users, such as increased profits through the digital marketing process as a form of marketing by applying digital technology with electronic media or internet and developing plans to attract consumer interest, reach a wider market anywhere without incurring excessive costs and carry put communication and transactions any time and also accessed by anyone considering many consumers have followed the flow of digitalization (Tayibnapis et al., 2021). The process of digitalization MSMEs certainly cannot happen instantly and still requires consistent develop and assistance, but there are ways or solutions that generally been widely implemented by joining digital platforms which is e-commerce that are already available like Shopee, Tokopedia and Bukalapak (Tayibnapis et al., 2021). 


\section{REFERENCES}

Andriani, D. P., Hamdala, I., Swara, S. E., \& Fadli, H. (2019). Perancangan Business Digital Platform dalam Mendukung Keberlanjutan IKM dengan Pendekatan Quality Function Deployment. Jurnal Ilmiah Teknik Industri, 18(1), 42-54. https://doi.org/10.23917/jiti.v18i1.7027

Febriyantoro, M. T., \& Arisandi, D. (2018). Pemanfaatan Digital Marketing Bagi Usaha Mikro, Kecil Dan Menengah Pada Era Masyarakat Ekonomi Asean. JMD: Jurnal Riset Manajemen \& Bisnis Dewantara, 1(2), 61-76. https://doi.org/10.26533/jmd.v1i2.175

Tayibnapis, A. Z., Wuryaningsih, L. E., \& Gora, R. (2021). Medium, Small and Medium Enterprises and Digital Platforms. South Asian Journal of Social Studies and Economics, 10(2), 10-19. https://doi.org/10.9734/sajsse/2021/v10i230258 